\title{
MAPPING SETTLEMENT QUALITY AND HEALTH CONDITION IN COASTAL AREA OF JEPARA DISTRICT 2019
}

\author{
Rido Feisal $^{1}$, Yasin Yusup ${ }^{2}$, Rita Noviani ${ }^{3}$ \\ ${ }^{123}$ Geography Education, Faculty of Teacher Training and Education, \\ Universitas Sebelas Maret Surakarta \\ E-mail : ridofeisal27@student.uns.ac.id
}

\begin{abstract}
The research Purposes is 1) Knowing coastal settlement quality at jepara district 2) Knowing coastal health condition level society 3) Knowing the correlation settlement quality between health level condition at Jepara District. The method used in this research is descriptive quantitative with spatial approach, the population in this research is settlement located at coastal area of Jepara District in 5 villages Demaan, Bulu, Kauman, Jobokuto, Ujungbatu. Technical sampling used proportional random sampling. Based on the result of the research the conclusion of the research is (1) settlement quality in coastal is on the good classified and medium classified for 34 settlement block which proportion 8 block is good classified and 26 block medium classified. The methode used is sattelite images interpretation and terrestrial. (2) health level condition in coastal has a various level from high classified and low classified if it is seen from incident rate of 5 diseases, based on administration demaan has the IR of 13,03 (low), Bulu 25,16 (high), Kauman 16,37 (low), Jobokuto 19,35 (normal), Ujungbatu 18,05 (normal) it shows that Demaan village has IR 13,03 it means there are 13 people which has illness out of 100. (3) correlation between settlement quality and health level condition in coastal has same direction but not too significant, with correlation value 0,275 (enough). correlation health level condition not only caused from settlement quality but it caused by many factor in that area.
\end{abstract}

Keyword : Settlement Quality, Incident Rate, Coastal, Correlation

\section{A. INTRODUCTION}

In General sense, map is a spatial and diagrammatic representation of element that we see on earth, often limited in two dimension like a surface and cartography is the discipline or science of contructing maps. Traditional mapping has been very useful for administrative, navigational, cultural and other purposes since ancient time. After an exlusive era of development and transformation, mapping concept has grown further witha fresh engagement between cartography and philoshopy that has either sought to refine and advance scientific cartography (Hossain \& Barata, 2019).

Settlement Geography is a branch of geography that learns human related to land use, water, natural resources, population density and the growth of the decisively settlements became an important part urban and urban design, the geography of the settlement focuses housing population and trying to figure out why always experience year by year 
changes (Balasubramaniam, 2015).

One alternative way that can be used is with remote sensing technology, remote sensing is a science that utilizes the sensors brought by vehicle to obtain information through recording the phenomenon of the earth's surface with help of natural and artificial energy sources. Succesfully recorded data is processed for a particular purpose. Remote sensing can be defines as the acquisition of the information about an object through a sensor that is not direct contact with object (Himayah et al., 2019), In this study remote sensing was used to obtain the quality of the settlement at coastal of Jepara district. Remote sensing data sources such as high-resolution images (e.g.,QuickBird and GeoEye) provide detailed data about specific surface feature. For example, in urban areas these images clearly depict individual buildings in slums, roads, and patterns of features (Alemie et al., 2015).

Settlement quality is defined as an area dominated by residential environment with the main function as a place to stay equipped with infrastructure and environmental and workplace facilities and has a standard in the physical environment of the settlement that can provide opportunities work to support the perilife and livelihoods so that the functions of the housing can be empowered and successful (UU RI Nomor 4 Tahun 1992 Tentang Perumahan Dan Permukiman, 1992).

Settlement quality changing push urban policy determinants to Monitoring and evaluation. The scale then is the measurement and evaluation high cost, many energy, and long time, considering the urban environment is very dense and crowded. Therefore required method Who are able to overcome these obstacles. One of the most popular techniques for Determining the quality of the settlement by using remote sensing data (Kurniadi, 2014). Increased population rapidly in developing countries cause the serious problem to the settlements, especially the settlements in the urban areas, it is not the balance between the number of people who need shelter with housing availability, especially in urban areas is a very urgent thing to consider the effort of the resolution (Nugroho, 2012).

Jepara district is located at the center of Jepara Regency which has a population of 90.425 people and has a population density of 3.365 people $/ \mathrm{km}^{2}$ which is spread in 16 villages, Jepara district is a coastal area, the phenomenon coastal settlement is present as a reflection of the presence of space which is influenced by the existence of the 
coast. Settlement conditions in the city are increasingly uncomfortable and insecure for the lower middle class because their space increasingly marginalized, many of the urban settlement that were initially good are slowly undergoing slum changes due to the addition of new buildings. The absence of adequate maintenance of facilities and infrastructure and unhealthy lifestyle cause settlements to be worse is known as taudification (Keputusan Menteri Negara Lingkungan Hidup Nomor : Kep45/MENLH/10/1997, 1997).

Characteristic of coastal areas is a dynamic and multidimensional force in playing area roles and functions. Characteristics of areas that have physical potential and cultural characteristics, which need to be optimized (Egam \& Rengkung, 2017). These conditions make the level public health is low, a slum environment is breeding ground for various types of diseases that originate from bacteria and viruses, the are many types of diseases associated with slum environmental conditions such as DHF (Dengue Hemorrhagic Fever), Malaria, TB (Tuberculosis), Diarrhea, URI (Upper Respiratory Tract Infection) (Priyono et al., 2013). The plague is caused by three main factors, namely lack of public awareness of environmental hygiene, durability body, and the increasingly strong viral distribution. Breeding the virus is closely related to the environment including the elevation, Rainfall, temperature, settlement density, population density (Undang-Undang No.23 Tahun 1992 Tentang Kesehatan, 1992).

Health science has limitations as a study of the dynamic of interactive relationships between population groups or communities with all kind of changes in environmental component that have the potensial to cause public health problems and prevention efforts (Priyono et al., 2013). Degree of health is an overview of the health condition generally occur in the community. In measuring or quantifying health conditions are conducted using the calculation of health conditions by looking at Incidence Rate or the risk of condition of disease during certain period in accordance with the statement (Rahmah, 2018).

This research was conducted in the coastal area at 5 villages of Demaan, Bulu, Kauman, Jobokuto and Ujungbatu because there are many people who work as fisherman and Jepara district as the center of economic activity in various fields including fisheries, agriculture, services and trade, which has triggered 
rapid population growth.

\section{B. MATERIALS AND METHODS}

The methode used in this research is descriptive quantitative with spatial approach, in this study the result is a map, the map will used to determine spatial phenomena. This study wants to prove or verify the presence or abscene of positive correlation between the quality of settlements and public health conditions of the people in the coastal district of Jepara in the year 2019. Data collection techniques used is field observation, image interpretation, interview and documentation. The technique of data analysis using the analysis of the spatial distribution, Incident Rate, scoring, statistical analysis. The determination of the settlement quality is done by interpretation of imagery by looking at interpretation variables coupled with terrestrial variables from (Direktorat Jenderal Cipta Karya-Departemen Pekerjaan Umum, 2006; Peraturan Pemerintah Republik Indonesia Nomor 66 Tahun 2014 Tentang Kesehatan Lingkungan, 2014) as follows:

\section{The quality settlement analysis coastal area in Jepara subdistrict 2019}

a. Density of settlements

$$
\text { Density of settlement }=\frac{\text { Total roof area }}{\text { Total area block settlement }} \times 100 \%
$$

Table 1. Density settlement parameter Source : Direktorat Jenderal Cipta Karya-Departemen Pekerjaan Umum 2006

\begin{tabular}{|c|c|c|c|}
\hline Num & Criteria & Class & Score \\
\hline 1 & $\begin{array}{l}\text { The average housing density in the settlement block } \\
\text { unit of }<40 \%\end{array}$ & Good & 3 \\
\hline 2 & $\begin{array}{l}\text { The average housing density in the settlement block } \\
\text { unit of } 40 \%-60 \%\end{array}$ & Medium & 2 \\
\hline 3 & $\begin{array}{l}\text { The average housing density in the settlement block } \\
\text { unit of }>60 \%\end{array}$ & Poor & 1 \\
\hline
\end{tabular}

b. Wide entrance road of settlement

Table 2. Wide entrance of settlement road parameter

\begin{tabular}{clcc}
\hline Num & \multicolumn{1}{c}{ Criteria } & Class & Score \\
\hline 1 & $\begin{array}{l}\text { The average entrance of }>6 \mathrm{~m} \text { with the assumption that } \\
\text { can be passed } 2 \text { or } 3 \text { cars freely }\end{array}$ & Good & 3 \\
2 & $\begin{array}{l}\text { The Average entrance of } 4 \mathrm{~m}-6 \mathrm{~m} \text { with the assumption } \\
\text { that can be passed } 1 \text { or } 2 \text { cars freely }\end{array}$ & Medium & 2 \\
3 & $\begin{array}{l}\text { The Average entry width of }<4 \mathrm{~m} \\
\text { Source : Direktorat Jenderal Cipta Karya-Departemen Pekerjaan Umum } 2006\end{array}$
\end{tabular}


c. Building pattern

Table 3. Building pattern parameter

\begin{tabular}{clcc}
\hline Num & \multicolumn{1}{c}{ Criteria } & Class & Score \\
\hline 1 & $\begin{array}{l}\text { When more than or equal to 50\% of buildings are } \\
\text { organized }\end{array}$ & Good & 3 \\
2 & When building 25\%-50\% of buildings are regularly & Medium & 2 \\
3 & When the $<25 \%$ of most buildings are less regular & Poor & 1 \\
\hline Source & Direktorat Jenderal Cipta Karya-Departemen Pekerjaan Umum 2006
\end{tabular}

d. Settlement road condition

Table 4. Settlement road condition parameter

\begin{tabular}{clcc}
\hline Num & \multicolumn{1}{c}{ Criteria } & Class & Score \\
\hline 1 & $\begin{array}{l}\text { Roads on the block settlements }>50 \% \text { have been in } \\
\text { cement and asphalt }\end{array}$ & Good & 3 \\
2 & $\begin{array}{l}\text { Roads on the block settlements 25\%-50\% have been in } \\
\text { cement and asphalt }\end{array}$ & Medium \\
3 & $\begin{array}{l}\text { The road on the settlement block of }<25 \% \text { has been in } \\
\text { cement and asphalt }\end{array}$ & Poor & 1 \\
\hline
\end{tabular}

Source : Direktorat Jenderal Cipta Karya-Departemen Pekerjaan Umum 2006

e. Tree line

$$
\text { Tree line }=\frac{\text { Tree cover area }}{\text { Block settlement area }} \times 100 \%
$$

Table 5. Tree Line parameter

\begin{tabular}{clcc}
\hline $\begin{array}{c}\mathrm{Nu} \\
\mathrm{m}\end{array}$ & \multicolumn{1}{c}{$\begin{array}{c}\text { Crit } \\
\text { eria }\end{array}$} & Class & $\begin{array}{c}\text { Scor } \\
\mathrm{e}\end{array}$ \\
\hline 1 & $\begin{array}{l}\text { Tree line on the left right side of the street block } \\
\text { settlement }>50 \%\end{array}$ & Good & 3 \\
2 & $\begin{array}{l}\text { Tree line on the left right side of the street block } \\
\text { settlements 25\%-50\% }\end{array}$ & $\begin{array}{c}\text { Mediu } \\
\mathrm{m}\end{array}$ & 2 \\
3 & $\begin{array}{l}\text { Tree line on the left right side of the street block } \\
\text { settlement }<25 \%\end{array}$ & Poor & 1 \\
\hline
\end{tabular}

Source : Direktorat Jenderal Cipta Karya-Departemen Pekerjaan Umum 2006

f. Flood

Table 6. Flood Perimeter

\begin{tabular}{|c|c|c|c|}
\hline Num & Criteria & Class & Score \\
\hline 1 & $\begin{array}{l}<25 \% \text { of the settlement block area is flooded during } \\
\text { the rainy season }\end{array}$ & Good & 3 \\
\hline 2 & $\begin{array}{l}25 \%-50 \% \text { of the settlement block area is flooded } \\
\text { during the rainy season }\end{array}$ & Medium & 2 \\
\hline 3 & $\begin{array}{l}>50 \% \text { of the settlement block area is flooded during } \\
\text { the rainy season }\end{array}$ & Poor & 1 \\
\hline
\end{tabular}

Source : Direktorat Jenderal Cipta Karya-Departemen Pekerjaan Umum 2006 
g. Location of settlement

Table 7. Settlement location parameter

\begin{tabular}{clcc}
\hline Num & \multicolumn{1}{c}{ Criteria } & Class & Score \\
\hline 1 & $\begin{array}{l}\text { Location of the settlement away from the source of } \\
\text { pollution (factories, markets, terminals, stations) with }\end{array}$ & Good \\
$\begin{array}{l}\text { a distance of } \pm 5 \mathrm{Km} \\
2\end{array}$ & $\begin{array}{l}\text { Location of settlements is not directly affected by } \\
\text { pollution source with a distance of } \pm 3 \mathrm{Km}\end{array}$ & Medium \\
3 & $\begin{array}{l}\text { Location of settlements very close to sources of } \\
\text { pollution or disaster prone areas with a distance of } \pm 1 \\
\text { Km }\end{array}$ & Poor & 1 \\
\hline
\end{tabular}

Source : Direktorat Jenderal Cipta Karya-Departemen Pekerjaan Umum 2006

h. Water Resources

Table 8. Water resources Parameter

\begin{tabular}{cccc}
\hline Num & Criteria & Class & Score \\
\hline 1 & $>50 \%$ of families using PDAM water & Good & 3 \\
2 & $25 \%-50 \%$ of families using PDAM water & Medium & 2 \\
3 & $<25 \%$ of families using PDAM water & Poor & 1 \\
\hline
\end{tabular}

Source : Direktorat Jenderal Cipta Karya-Departemen Pekerjaan Umum 2006

i. Sanitation

Table 9. Sanitation Parameter

\begin{tabular}{cccc}
\hline Num & Criteria & Class & Score \\
\hline 1 & $>50 \%$ of families using waste channels and WC & Good & 3 \\
2 & $25 \%-50 \%$ of families using waste channels and WC & Medium & 2 \\
3 & $<25 \%$ of families using waste channels and WC & Poor & 1 \\
\hline
\end{tabular}

Source : PP Nomor 66 Tahun 2014 Tentang Kesehatan Lingkungan, 2014

j. Waste service and garbage availability

Table 10. Waste service and garbage availability parameter

\begin{tabular}{clcc}
\hline Num & \multicolumn{1}{c}{ Criteria } & Class & Score \\
\hline 1 & $\begin{array}{l}>50 \% \text { of Families threw waste to the garbage plus a } \\
\text { waste disposal officer and there is a Garbage }\end{array}$ & Good & 3 \\
2 & $\begin{array}{l}25 \%-50 \% \text { of Families threw waste to the garbage plus } \\
\text { a waste disposal officer and there is a Garbage } \\
\text { < 25\% of Families threw waste to the garbage plus a } \\
\text { waste disposal officer and there is a Garbage }\end{array}$ & Poor & 1 \\
\hline
\end{tabular}

Source : PP Nomor 66 Tahun 2014 Tentang Kesehatan Lingkungan, 2014

Each settlement block is given a value that relies on each quality parameter of the residential environment which is then grouped and performed scoring which later in classifying by class on each parameter as follows: 
Table 11. Weighing Factor

\begin{tabular}{clc}
\hline Number & \multicolumn{1}{c}{ Parameter } & Weighing factor \\
\hline 1 & Density of settlement & 3 \\
2 & Wide entrance of settlement road & 3 \\
3 & Building pattern & 1 \\
4 & Settlement road condition & 2 \\
5 & Tree Line & 2 \\
6 & Flood & 3 \\
7 & Location of settlement & 2 \\
8 & Water resources & 3 \\
9 & Sanitation & 3 \\
10 & Waste Service and Garbage Availability & 3 \\
\hline
\end{tabular}

Source : Direktorat Jenderal Cipta Karya-Departemen Pekerjaan Umum 2006

The valuation of the quality of the Settlement class is carried out after the grading process, the assessment on each variable, the environmental quality of the class is based on the number of each determinant parameter multiplied by the balance factor respectively and Then Description :

I : Class Interval

R: Highest score - Lowest Score N: Number of classes desired $I=\frac{R}{N}$

At the determination of this research class based on analysis is known that class intervals as follows:

$$
\begin{aligned}
I & =\frac{75-25}{3} \\
I & =\frac{50}{3} \\
I & =17
\end{aligned}
$$

The acquisition of figures from 75 and 25 is derived from the sum and multiplication of the weighing factors seen from when the highest and lowest sum the result, If the total score is known then done by determining the class or classification, this classification intends for the determination of the settlement block class into the class of good, medium, or poor by the interval (range) formula as follows:

Table 12. Scoring settlement quality

\begin{tabular}{ccc}
\hline Total Value & Criteria & Class \\
\hline $52-68$ & Good Quality & I \\
$35-51$ & Medium Quality & II \\
$17-34$ & Poor Quality & III \\
\hline
\end{tabular}

Source : Data Analysis 2019 
Based on the data analysis above, you can know the quality level of coastal settlements of Jepara subdistrict then conducted geographic information system analysis with the help of software ARC Gis 10.3 and produce quality map of coastal settlement Jepara subdistrict year 2019 with a scale of $1: 12,000$

\section{Health condition analysis of coastal} communities Jepara District 2019

Health analysis using Incident Rate (IR) which is a comparison of population value to the number of pain figures of people with disease, in which 100 people can be known how many sufferers. The calculation of IR uses all kinds of diseases either infectious or not contagious, especially due to the quality conditions of the residential environment are not good. There are five types of diseases that are used as a data analysis of the authors of DHF, TUBERCULOSIS, URI, Malaria and diarrhea but previously should be known number of pain in each village.

Description :

$$
\text { Incidence Rate }=\frac{A}{C} \times K
$$

A : The number occurrences of certain diseases that occur within a certain period
$\mathrm{C}$ : The number of people who have the risk of experiencing certain diseases

$\mathrm{K}$ : Population multiplication Constants $(100,1000,10,000$ etc $)$

Based on the result of IR classification for the total of all diseases above, then can be known level of health condition of coastal community of Jepara subdistrict which quite varied in each villages. Then the calculations to know the classification by using the Sturgess calculation method is the highest value minus the lowest value of the calculation of Incident Rate divided by the number of classes to be used, from the calculation can be determined the Incident Rate classification value so that it can be known to public health.

$$
\begin{aligned}
& \text { Range }=\text { Highest Data }- \text { Lowest Data } \\
& =R
\end{aligned} \quad \begin{aligned}
& \text { Number of classes }(k)=1+3,3 \log n \\
& \text { Class Interval }(i)=\frac{R}{k}=i
\end{aligned}
$$

Description :

$\mathrm{R}$ : The highest and lowest data difference

$\mathrm{k}$ : Number of classes

$\mathrm{n}$ : Amount of data owned

$\mathrm{i}$ : Class Interval

\section{The analysis of quality relations of} settlements with public health
conditions

Relationship analysis is done by statistical testing. The statistical test used is a non-parametric test, a nonparametric test used because the data to be analyzed is ordinal type data which is 
then tested using the Rank Spearman test. In this test is carried out the relationship between the data of the quality of settlement analysis with public health components, the quality of the settlements seen through each Village or village based on the quality of each settlement block in Every Villages that is then grouped and then made the weighted each block so that the data is known to each village has a good settlement quality. Medium, or poor.

The analysis of the relationship is done by looking at the secondary data that is a component of public health by looking at the number of sick or the number of people with diseases that are seen from the indicators of five diseases that are related to the condition Environmental. Then if the data is already known and connected with the results of the quality analysis of the previously known settlements for each village that later known there is a relationship or absence. This analysis is related to the comparison of the quality of settlement in the event of disease in the research area of the research location of good quality, assumed the incidence of illness will be slight, but when the Location with good quality of settlements have a high incidence of disease then can be detected an error occurred at the time of assessment on each parameter.

\section{RESULTS AND DISCUSSION}

\section{The coastal block spread of Jepara subdistrict}

Based on land use map data and imagery interpretation of the coastal areas of Jepara subdistrict can be done determination of the settlement blocks by looking at the boundaries of the settlement block of the road or on a block of settlements surrounded by roads and Known as the block of blocks amounted to 34 , then blocks are given numbering to facilitate the analysis process, the surface block is used as the main reference of data analysis for the determination of the quality of settlements by the line of each settlement block. Based on figure 1 can be seen grouping of the settlement block by the street lines so can be obtained as 34 block settlement. 


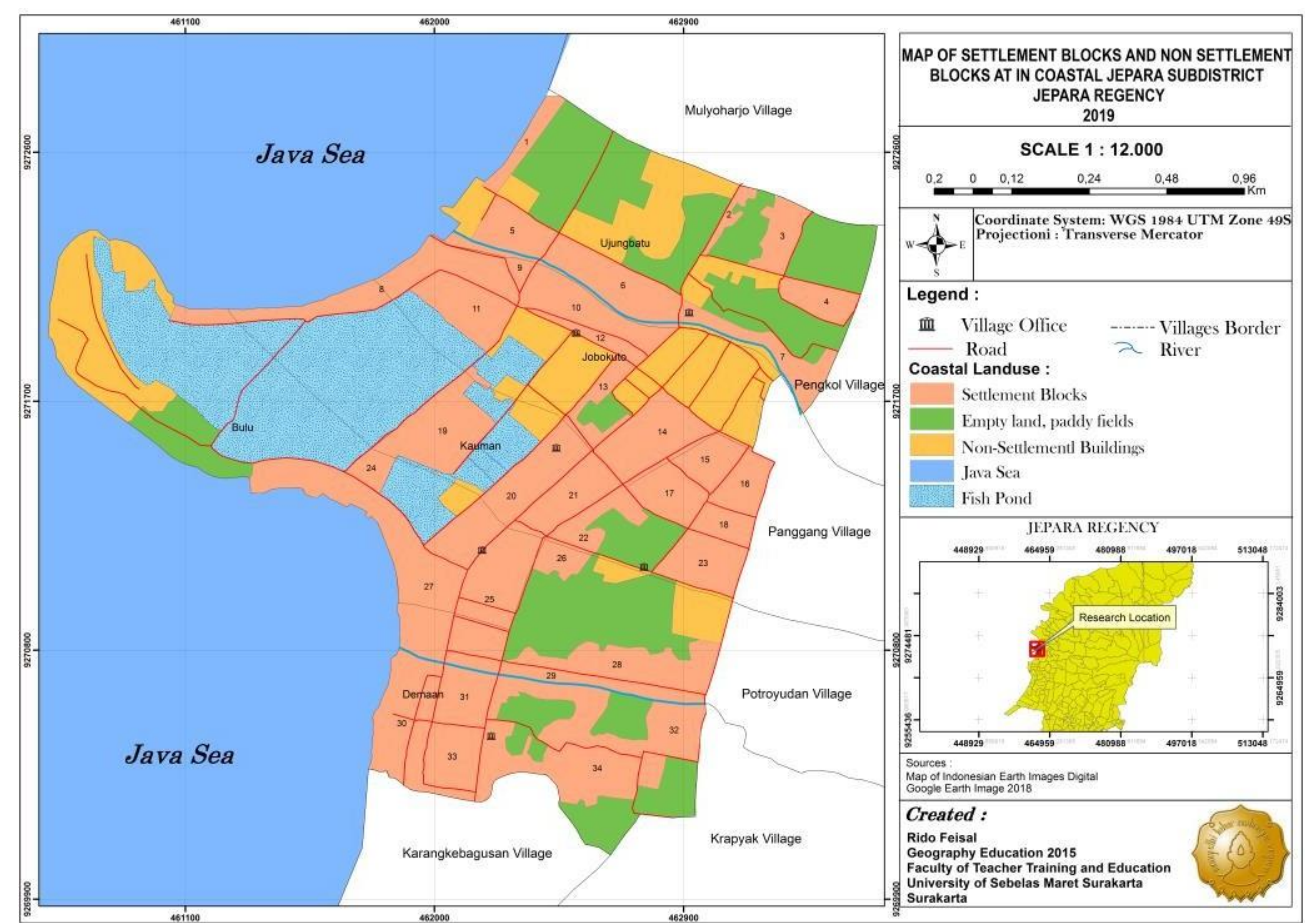

Figure 1. Map of Settlement Blocks and Non Settlement Coastal Area Jepara District 2019

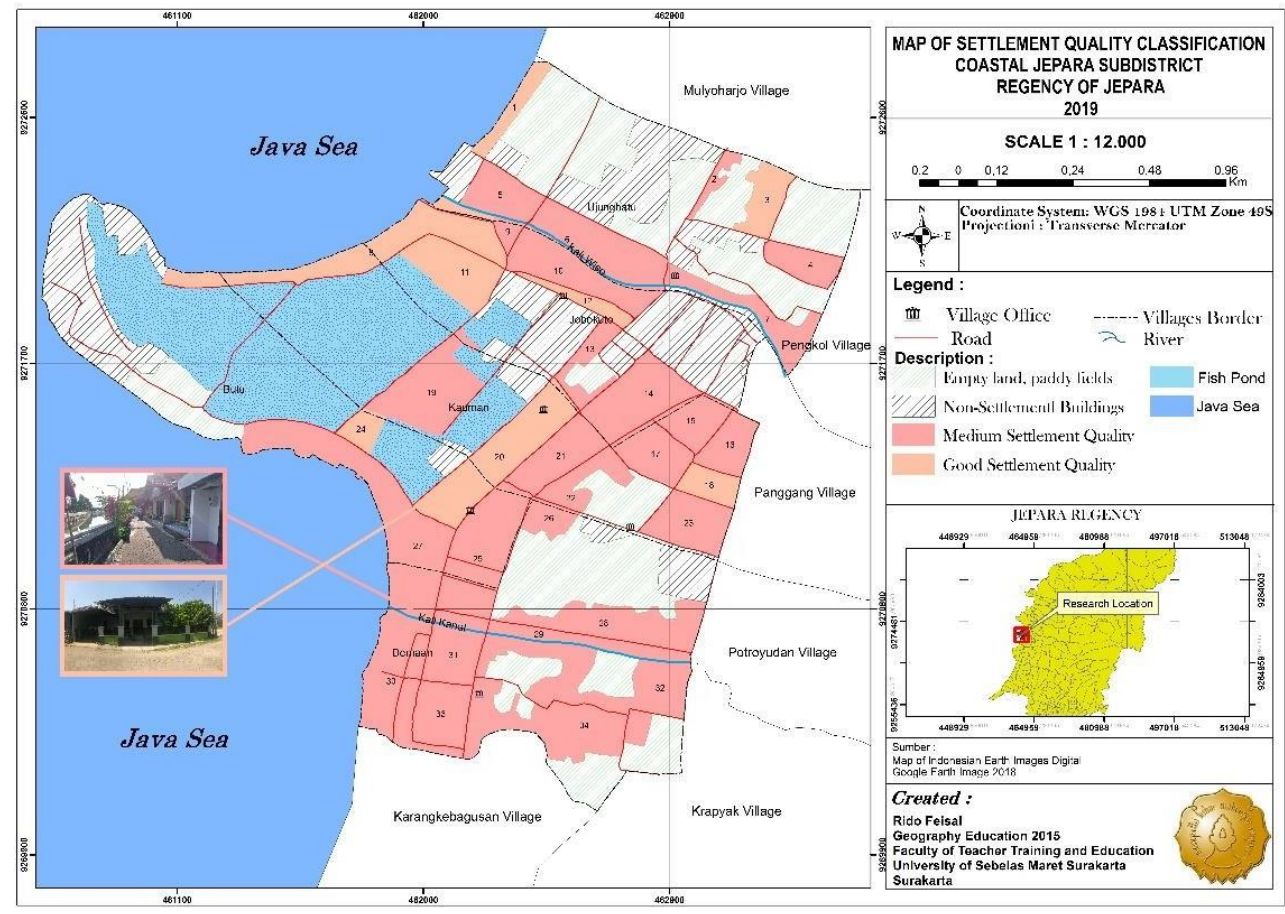

Figure 2. Map of Block based on Settlement Quality Coastal Area Jepara District year 2019

Based on the results of the scoring in each of the settlement quality variables can be known level of quality of the surface, as in the
Figure 2 there is known a settlement block with good quality and medium that Scattered in the coastal district of Jepara such as in good quality there 
are 8 blocks $(1,3,8,11,12,18,20$,

24) and in medium quality there are

26 blocks $(2,4,5,6,7,9,10,13,14$,

$1,16,17,19,21,22,23,25,26,27$,
$28,29,30,31,32,33,34)$. These

following the quality settlements based on the number of settlement blocks:

Table 13. Number of blocks based on settlement of coastal areas Jepara subdistrict

\begin{tabular}{clcccc}
\hline Num & Criteria & $\begin{array}{c}\text { Total } \\
\text { Value }\end{array}$ & $\begin{array}{c}\text { Number of } \\
\text { Blocks }\end{array}$ & Class & Percentage (\%) \\
\hline 1 & Good & $51-68$ & 8 & I & 23,5 \\
2 & Medium & $35-51$ & 26 & II & 76,5 \\
3 & Poor & $17-34$ & 0 & III & - \\
\hline & Amount & & 34 & & \\
\hline
\end{tabular}

Source : Data Analysis 2019

Based on the table can be known the number of blocks that are included in the good quality are 8 blocks and medium quality are 26 blocks, for the classification of the class is divided into 3 classes, based on the results of calculations 8 blocks into class I and 26 blocks class II , with an area of all for good quality of $23.5 \%$ and medium of $76.5 \%$.

\section{Relation between settlement quality and public health conditions}

Table 14 Community health level of coastal areas Jepara (Incident Rate IR)

\begin{tabular}{clccccc}
\hline Num & Village & Population & $\begin{array}{c}\text { Total } \\
\text { Number of } \\
\text { Ilness }\end{array}$ & IR & Class Interval & Classification \\
1 & Demaan & 7245 & 944 & 13,03 & $13,03-17,54$ & Low \\
2 & Bulu & 4272 & 1075 & 25,16 & $22,07-26,58$ & High \\
3 & Kauman & 4654 & 762 & 16,37 & $13,03-17,54$ & Low \\
4 & Jobokuto & 5990 & 1159 & 19,35 & $17,55-22,06$ & Medium \\
5 & Ujungbatu & 4987 & 900 & 18,05 & $17,55-22,06$ & Medium \\
\hline
\end{tabular}

Source : Primary and Secondary Data analysis 2019

Table 15 Quality settlements and health conditions of the coastal areas of Jepara

\begin{tabular}{clccc}
\hline Num & Village & Settlement Classification & IR & IR Classification \\
\hline 1 & Demaan & Medium & 13,03 & Low \\
2 & Bulu & Medium & 25,16 & High \\
3 & Kauman & Medium & 16,37 & Low \\
4 & Jobokuto & Medium & 19,35 & Medium \\
5 & Ujungbatu & Medium & 18,05 & Medium \\
\hline
\end{tabular}

Sumber : Primary and secondary Data analysis 2019 
Number of correlation coefficient in the result of data processing with the help of SPSS software, positive value that is 0.275 , so the relationship of the two variables are in same direction, thus it can be interpreted that the quality of poor grade block is increased then IR number will increase, the greater the value of IR then the level of public health will also be low.

Criteria of significance correlation if the value of Sig. (2-tailed) calculation result is smaller than the value of 0.05 then there is said significant relationship. But the value of the Sig. (2-tailed) calculation result is greater than the value of 0.05 hence there is no significant relationship between the two variables. Based on the output in the calculation generates a value of Sig. (2-tailed) of 0.116, due to the value of Sig. (2- tailed) $0.116>0.05$ It can be interpreted that there is no significant (mean) link between the IR variables and the quality of the block. The relationship that toward to public health is not only from the quality of this settlement because the indicator of health level is not only influenced by one factor that is the quality of settlement factor but many factors that influence on A region.

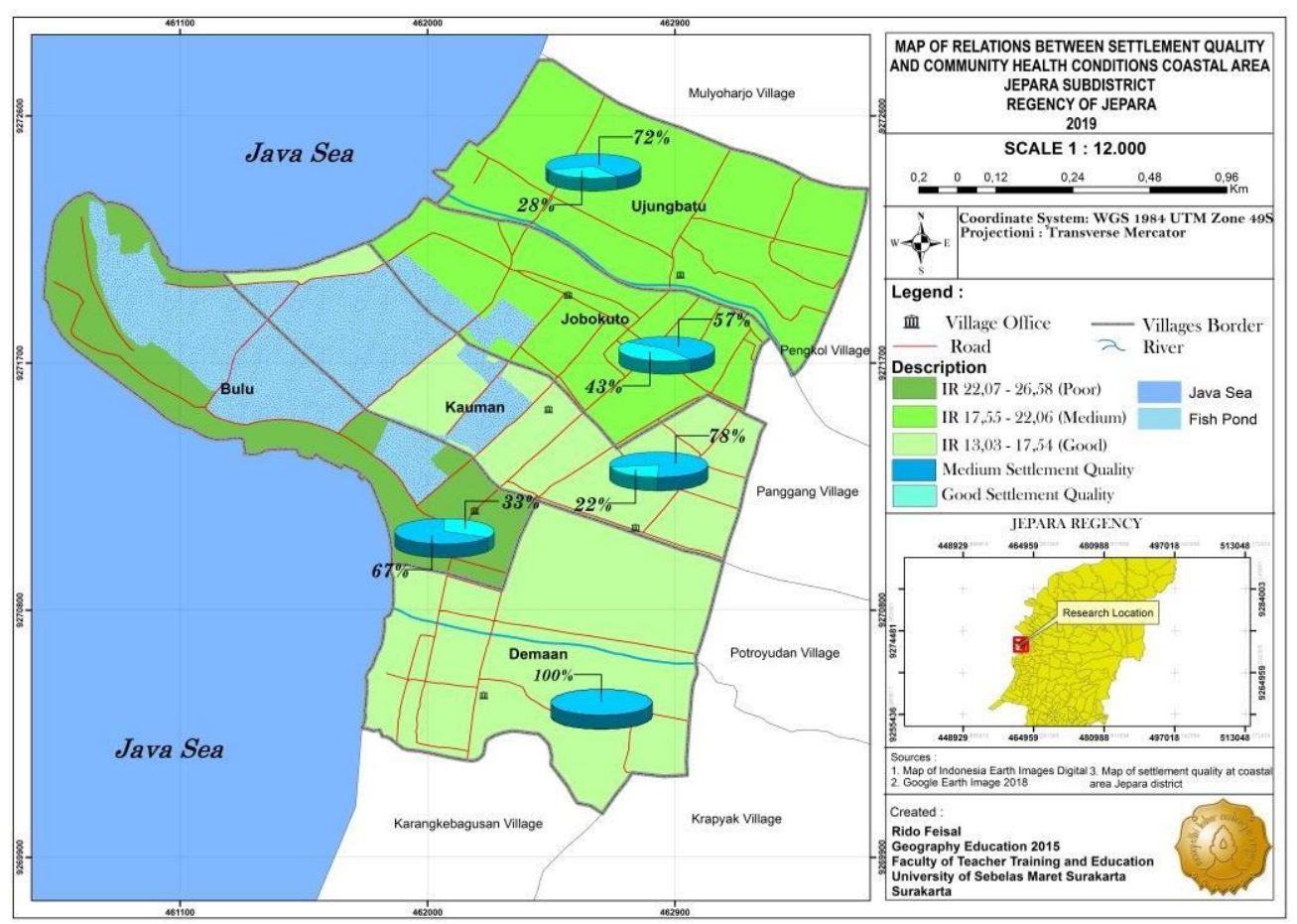

Figure 3. Map of Relations of the quality of settlements and public health conditions in the coastal of Jepara subdistrict 2019 


\section{CONCLUSIONS}

Condition of quality of settlement level in the coastal area of Jepara subdistrict has a settlement class with a medium level of 26 blocks with an area of 148 , $1 \mathrm{Ha}$ and a class of both 8 blocks with an area of $38,6 \mathrm{Ha}$. It can be concluded that the coastal area of Jepara subdistrict is dominated by the settlement block with medium quality. The medium quality of the settlement is dominated in block that have high population density and also the area that is on the side of the river. Community health condition of coastal areas based on the calculation of the Incident Rate of 5 diseases known that the level of public health conditions Jepara subdistrict Especially in the coastal area is quite varied, namely entry into high, medium and low class that can be seen in table 2 . Incident Rate can show many number of sufferers in 100 inhabitants in each village as an example at Demaan

\section{E. REFERENCES}

Alemie, B. K., Bennett, R. M., \& Zevenbergen, J. (2015). A Socio-Spatial Methodology for Evaluating Urban Land Governance: The Case of Informal Settlements. Journal of Spatial Science, 60(2), 289309.

https://doi.org/10.1080/144985 $\underline{96.2015 .1004654}$ village its IR number 13.03 so that every 100 peoples then there are 13.08 sufferers, the greater the number Incident Rate The condition of health will be poor. The relationship that toward to public health is not only from the quality of this settlement because the indicator of health level is not only influenced by one factor. Environmental factors that cause the level of public health conditions are the environmental conditions adjacent to the coast and adjacent to ponds that cause mosquitoes and also from the activities of plant pollution, waste and adjacent to the large rivers plus also by genetic factors of everyone's descent. To improve the health condition of good society can be done some things such as maintaining the condition of environmental quality is to dispose of waste in place will bring about healthy life behavior so that the environment becomes comfortable and healthy.

Balasubramaniam, A. (2015). Human Settlement Systems. Presentation, July 2015, 11.

Direktorat Jenderal Cipta KaryaDepartemen Pekerjaan Umum. (2006). Pedoman Identifikasi Kawasan Permukiman Kumuh Daerah Penyangga Kota Metropolitan. Umum, 
Direktorat Jenderal Cipta Karya - Departemen Pekerjaan.

Egam, P., \& Rengkung, M. (2017). Analisis Visual Kawasan Pesisir Pantai (Studi Kasus Permukiman Masyarakat LOS di Pesisir Pantai Malalayang). Jurnal Arsitektur DASENG, 6(1), 21-31.

Keputusan Menteri Negara Lingkungan Hidup Nomor : Kep-45/MENLH/10/1997, Peraturan BKPM 7 (1997). https://peraturan.bkpm.go.id/jdi h/userfiles/batang/MENLH_KE P45_1997.pdf

Himayah, S., . D., Ismail, A., \& . N. (2019). Settlement Quality Mapping Around Universitas Pendidikan Indonesia (UPI) in Relation to Student Learning Achievement. KnE Social Sciences, 2019, 760-772. https://doi.org/10.18502/kss.v3i 21.5009

Hossain, S., \& Barata, F. T. (2019). Interpretative mapping in cultural heritage context: Looking at the historic settlement of Khan Jahan in Bangladesh. Journal of Cultural Heritage, 39, 297-304. https://doi.org/10.1016/j.culher. 2018.09.011

Undang-Undang No.23 Tahun 1992 tentang Kesehatan, (1992).

Kurniadi, A. (2014). Analisis Kualitas Lingkungan Permukiman di Kecamatan Kotagede Kota Yogyakarta Menggunakan Citra Quickbird
[Universitas

Negeri

Yogyakarta]

https://repositories.lib.utexas.ed u/handle/2152/39127\%0Ahttps: //cris.brighton.ac.uk/ws/portalfi les/portal/4755978/Julius+Ojeb ode\%27s+Thesis.pdf\%0Ausir.s alford.ac.uk/29369/1/Angela_D arvill_thesis_esubmission.pdf\% 0Ahttps://dspace.lboro.ac.uk/ds pace-jspui/ha

Peraturan Pemerintah Republik Indonesia Nomor 66 Tahun 2014 tentang Kesehatan Lingkungan, (2014). https://doi.org/10.1017/CBO97 81107415324.004

Nugroho, E. (2012). Pemanfaatan Citra IKONOS untuk Kajian Kualitas Permukiman di Kecamatan Colomadu Kabupaten Karanganyar. Universitas Sebelas Maret.

UU RI Nomor 4 Tahun 1992 tentang Perumahan dan Permukiman, (1992).

Priyono, Jumadi, \& Kurniasari, M. I. (2013). Pengukuran Kualitas Permukiman Hubungannya dengan Tingkat Kesehatan Masyarakat di Kecamatan Sragen: Upaya Awal untuk Peningkatan Kapasitas Masyarakat dalam Strategi Pengurangan Risiko Penyakit. Geo Edukasi, 2(1), 52-59.

Rahmah, A. (2018). Pemodelan Faktor Risiko Penyakit Campak Pada Balita di Provinsi DKI Jakarta. Institut Pertanian Bogor. 